\title{
Effects of Hydrogen Peroxide and Sodium Hypochlorite Aging on Properties and Performance of Polyethersulfone Ultrafiltration Membrane
}

\author{
Kai Li ${ }^{1,2, *}$, Shu Li ${ }^{1,2}$, Qian Su ${ }^{1,2}$, Gang Wen ${ }^{1,2}$ and Tinglin Huang ${ }^{1,2, *}$ \\ 1 Key Laboratory of Northwest Water Resource, Environment and Ecology, MOE, Xi'an University of \\ Architecture and Technology, Xi'an 710055, China; sisl2018@163.com (S.L.); \\ sunflower190901@sina.com (Q.S.); hitwengang@163.com (G.W.) \\ 2 Shaanxi Key Laboratory of Environmental Engineering, Xi'an University of Architecture and Technology, \\ Xi'an 710055, China \\ * Correspondence: likai@xauat.edu.cn (K.L.); huangtinglin@xauat.edu.cn (T.H.); Tel.: +86-29-8220-7886 (K.L.); \\ +86-29-8220-1038 (T.H.)
}

Received: 20 September 2019; Accepted: 16 October 2019; Published: 18 October 2019

\begin{abstract}
Chemical reaction of main polymer and additive with oxidative cleaning agents plays an important role in aging of polymeric membrane for water and wastewater treatment. As a green and powerful oxidant, hydrogen peroxide $\left(\mathrm{H}_{2} \mathrm{O}_{2}\right)$ can achieve good cleaning efficacy under alkaline condition, but its influence on membrane aging was poorly understood. In this study, degradation of polyethersulfone (PES) membrane due to $\mathrm{H}_{2} \mathrm{O}_{2}$ exposure under alkaline condition ( $\mathrm{pH} 9$ and 11) was holistically investigated by humic acid (HA) filtration experiments and multiple membrane characterization techniques, with sodium hypochlorite $(\mathrm{NaClO})$ aging examined as a comparison. Membrane permeability and $\mathrm{HA}$ retention rate was hardly changed by $\mathrm{H}_{2} \mathrm{O}_{2}$ aging at an exposure dose of $500 \mathrm{~g} \cdot \mathrm{h} / \mathrm{L}$, whereas $\mathrm{NaClO}$ aging led to substantial increase of membrane permeability and significant decrease of retention ability. Meanwhile, $\mathrm{H}_{2} \mathrm{O}_{2}$ aging slightly increased fouling propensity with HA filtration, while $\mathrm{NaClO}$ aging resulted in more serious fouling. ATR-FTIR and XPS analysis revealed much less degradation of PES and hydrophilic additive by $\mathrm{H}_{2} \mathrm{O}_{2}$ than that by $\mathrm{NaClO}$, and membrane morphology and surface properties were characterized to explain the variation of filtration performance. Overall, compared with cleaning with $\mathrm{NaClO}$, membrane degradation can be minimized by cleaning with $\mathrm{H}_{2} \mathrm{O}_{2}$.
\end{abstract}

Keywords: chemical cleaning; membrane aging; polyethersulfone (PES) ultrafiltration (UF) membrane; hydrogen peroxide $\left(\mathrm{H}_{2} \mathrm{O}_{2}\right)$; sodium hypochlorite $(\mathrm{NaClO})$

\section{Introduction}

Ultrafiltration (UF) is an established technology for water and wastewater treatment due to its excellent rejection towards particulates and pathogens, small footprint, and acceptable capital and operation costs [1,2]. However, its wide application is restricted by membrane fouling, which is an inherent drawback of membrane technology [3]. Although membrane fouling can be alleviated by several strategies, such as development of anti-fouling membrane, pretreatment of feed water, and optimization of operation parameters, physically irreversible fouling is still inevitable during long-term operation [4]. Therefore, chemical cleaning is indispensable for the sustainable running of UF system [5]. Acids, bases, oxidants, surfactants, complexing agents, etc. can be used as membrane cleaning agents [6]. Among these cleaning agents, oxidative agents are widely used for membrane cleaning in the water industry because of their high cleaning efficacy for organic and biological fouling, which are major types of fouling in UF for water and wastewater treatment [5,7]. 
Sodium hypochlorite $(\mathrm{NaClO})$ is one of the most commonly used oxidative cleaning agents because of its high efficiency, low cost, and being easy to use [8]. It can disinfect microorganisms adhering to membrane surface, and detach organic and biological foulants from membrane surface by altering their properties [5,9]. However, the reaction of $\mathrm{NaClO}$ with organics would generate toxic halogenated by-products, which is an important threat to environmental and public health [10]. More importantly, degradation of membrane materials due to $\mathrm{NaClO}$ exposure can alter properties and performance of membrane, and subsequently influence membrane system operation and its lifespan $[6,11]$. It was found that polyvinylpyrrolidone (PVP), a widely used hydrophilic additive for polyethersulfone (PES) membrane, exhibits high reactivity with $\mathrm{NaClO}$. Surface charge, hydrophilicity, and pore structure might be changed due to oxidation and dislodgement of PVP by $\mathrm{NaClO}[6,12]$. As for the main polymer (i.e., PES) with much higher chemical stability, several studies have reported PES chain scission and/or hydroxylation of PES aromatic rings [13-15]. Besides, it was reported that degradation of PES membrane by $\mathrm{NaClO}$ was more serious under neutral to weak alkaline conditions, which has been attributed to the formation of hydroxyl radical $[14,16,17]$.

Hydrogen peroxide $\left(\mathrm{H}_{2} \mathrm{O}_{2}\right)$ is a strong oxidant with a standard reduction potential of $1.78 \mathrm{~V}$, but its reactivity is restricted by a relatively high activation energy barrier $[18,19]$. Although its application as an oxidative cleaning agent is not as wide as that of $\mathrm{NaClO}$, its effectiveness for permeability recovery has been demonstrated in several studies [20,21]. It was found that $\mathrm{H}_{2} \mathrm{O}_{2}$ cleaning under strong alkaline condition can achieve comparable cleaning efficacy with $\mathrm{NaClO}$ for cleaning of UF membrane fouled by humic substances [18]. Moreover, compared with $\mathrm{NaClO}$ cleaning, $\mathrm{H}_{2} \mathrm{O}_{2}$ cleaning can avoid the formation of toxic halogenated by-products. Therefore, $\mathrm{H}_{2} \mathrm{O}_{2}$ is regarded as a potential alternative cleaning agent of the widely used $\mathrm{NaClO}$ [6]. However, only a few papers have investigated aging of polymeric membrane by $\mathrm{H}_{2} \mathrm{O}_{2}$. Ling et al. [22] and $\mathrm{Yu}$ et al. [23] focused on the degradation of polyamide-based reverse osmosis and nanofiltration by $\mathrm{H}_{2} \mathrm{O}_{2}$. With respect to UF membrane, the effects of $\mathrm{H}_{2} \mathrm{O}_{2}$ enhanced backwashing on the mechanical properties and surface functional groups of polyvinylidene fluoride membrane has been examined [24]. In general, aging of UF membrane due to $\mathrm{H}_{2} \mathrm{O}_{2}$ cleaning is poorly understood.

The main purpose of this study was to comprehensively investigate degradation of PES membrane caused by $\mathrm{H}_{2} \mathrm{O}_{2}$ aging, with $\mathrm{NaClO}$ aging examined as comparison. PES membrane was soaked in $\mathrm{H}_{2} \mathrm{O}_{2}$ and $\mathrm{NaClO}$ solutions with a concentration of $5000 \mathrm{mg} / \mathrm{L}$ to accelerate membrane aging, and an exposure dose of $500 \mathrm{~g} \cdot \mathrm{h} / \mathrm{L}$ was selected based on chemical cleaning parameters and frequency generally applied in water and wastewater treatment $[6,25]$. Membrane permeability, fouling propensity, and retention ability of membranes were examined to evaluate membrane degradation in macroscopic scale. Meanwhile, chemical composition and physicochemical properties of pristine and aged membranes were characterized holistically to elucidate degradation mechanisms and explain the variation in filtration performance.

\section{Materials and Methods}

\subsection{Chemical Agents}

All chemicals and reagents used in this study were analytical grade. Commercial available $\mathrm{H}_{2} \mathrm{O}_{2}(\sim 30 \% \mathrm{wt})$ and $\mathrm{NaClO}(\sim 10 \% \mathrm{wt})$ were purchased from Tianli Chemical Reagent Co. (Tianjin, China) and Kermel Chemical Reagent Co. (Tianjin, China), respectively. Concentrations of $\mathrm{H}_{2} \mathrm{O}_{2}$ and $\mathrm{NaClO}$ solution were determined by permanganate titration method [26] and iodometric titration method [27], respectively, and therefore the reported concentrations were sum of all active species in the solutions. $\mathrm{HCl}$ and $\mathrm{NaOH}$ were both obtained from Chemical Reagent $\mathrm{Co}$. (Tianjin, China). Humic acid (HA) obtained from Sigma-Aldrich Chemical Co. (St. Louis, MO, USA) was used to evaluate the retention ability and fouling propensity of pristine and aged membranes. Ultrapure water prepared by PURELAB Option-R system (ELGA LabWater, High Wycombe, UK) was used to prepare solutions. 


\subsection{Membranes and Accelerated Aging Procedure}

A commercially available flat-sheet PES membrane (UP 150 P, Microdyn-Nadir, Germany) was used in this study, and its main characteristics are listed in Table S1 in the Supplementary Information. According to the manufacturer, the molecular weight cut-offs (MWCOs) of the membrane was $150 \mathrm{kDa}$. To ensure the removal of preservatives before use, new membranes were soaked in ultrapure water for $36 \mathrm{~h}$ and the water was replaced every $12 \mathrm{~h}$.

In the accelerated aging procedure, $\mathrm{H}_{2} \mathrm{O}_{2}$ and $\mathrm{NaClO}$ solutions with a concentration of $5000 \mathrm{mg} / \mathrm{L}$ were used as aging solutions, and the membranes were soaked in the aging solutions at ambient temperature $\left(25 \pm 2{ }^{\circ} \mathrm{C}\right)$ in the dark for $100 \mathrm{~h}$ to obtain an aging intensity (concentration $\times$ time, $\mathrm{ct}$ ) of $500 \mathrm{~g} \cdot \mathrm{h} / \mathrm{L}$. Aging solutions at $\mathrm{pH} 9$ and 11 were examined because oxidative cleaning agents are usually combined with bases to achieve higher cleaning efficiencies [21,28,29]. The $\mathrm{pH}$ of $\mathrm{H}_{2} \mathrm{O}_{2}$ and $\mathrm{NaClO}$ solutions were adjusted to 9 and 11 using $\mathrm{HCl}$ or $\mathrm{NaOH}$. Meanwhile, to differentiate the influence of $\mathrm{H}_{2} \mathrm{O}_{2}$ and $\mathrm{NaClO}$ aging from that of alkaline exposure, $\mathrm{NaOH}$ solutions with $\mathrm{pH} 9$ and 11 were also used as aging solutions, and the membrane samples aged in $\mathrm{NaOH}$ were denoted as control membrane. To avoid the concentration decay of $\mathrm{H}_{2} \mathrm{O}_{2}$ and $\mathrm{NaClO}$, aging solutions were replaced every $24 \mathrm{~h}$ during the experiment. After $100 \mathrm{~h}$ soaking in aging solutions, the membranes were rinsed thoroughly and soaked in ultrapure water for another $24 \mathrm{~h}$ before characterization and performance evaluation.

\subsection{Evaluation of Membrane Performance}

Pure water permeability, retention ability, and fouling propensity of pristine and aged membranes were evaluated by filtration experiments conducted in a filtration cell (Amicon 8400, Millipore, MA, USA $)$ in dead-end mode at room temperature $\left(25 \pm 2{ }^{\circ} \mathrm{C}\right)$. The UF cell was operated in constant pressure mode with nitrogen gas supplying the driving force, and the trans-membrane pressure (TMP) was kept at $60 \mathrm{kPa}$. Permeate weight was quantified by an electronic balance connected to a computer and the data were automatically recorded every five seconds.

Fouling propensity and retention ability of pristine and aged membranes were examined by using HA solution as the feed water. The concentration of HA employed in this study was $10 \mathrm{mg} / \mathrm{L}$, and the $\mathrm{pH}$ was adjusted to $7.5 \pm 0.1$ with $0.1 \mathrm{~mol} / \mathrm{L} \mathrm{HCl}$ or $\mathrm{NaOH}$. To simulate the solution chemistry of natural waters, $1 \mathrm{mmol} / \mathrm{L}$ of $\mathrm{NaHCO}_{3}, 1 \mathrm{mmol} / \mathrm{L}$ of $\mathrm{CaCl}_{2}$, and $6 \mathrm{mmol} / \mathrm{L}$ of $\mathrm{NaCl}$ was added [30]. In each filtration test, $350 \mathrm{~mL}$ of $\mathrm{HA}$ solution was added to the filtration cell, and filtration was carried out under a TMP of $60 \mathrm{kPa}$ until the permeate volume reached $300 \mathrm{~mL}$. Based on initial and final permeate flux as well as permeate volume per unit membrane surface area, the unified membrane fouling index (UMFI) can be calculate to evaluate membrane fouling propensity [16,31]. With respect to retention ability, HA concentrations of feed solution $\left(C_{\mathrm{f}}\right)$ and permeate $\left(C_{\mathrm{p}}\right)$ were measured in terms of UV absorbance at $254 \mathrm{~nm}$ using a UV/Vis spectrophotometer (U-3900, Hitachi, Tokyo, Japan). Membrane retention ability was quantified by the retention rate of HA (Equation (1)).

$$
\text { HA rejection rate }=\left(1-\frac{C_{p}}{C_{f}}\right) \times 100
$$

\subsection{Characterization of Membrane Properties}

To monitor the changes in functional groups of the membranes, Fourier transform infrared (FTIR) spectrum in the range of $400-4000 \mathrm{~cm}^{-1}$ was acquired using an infrared spectrometer (Nicolet iS50, Thermo Scientific, MA, USA). The spectral resolution of the spectrometer was set to be $4 \mathrm{~cm}^{-1}$ and each spectrum was an average of 32 scans. X-ray photoelectron spectroscopy (XPS) analysis was performed with a XPS spectrometer (K-Alpha, Thermo Scientific, MA, USA). The deconvolution method of the XPS spectrum was obtained by fitting a Gaussian function. Morphology of membrane surface was observed using a scanning electron microscope (SEM, Quanta 600, FEI, OR, USA). Membrane samples were coated with a thin gold film (3-5 nm) using a precision etching coating system (Model 682, Gatan, USA) before observation. 
Membrane surface charge was measured by an electrokinetic analyzer (SurPASS, Anton Parr, Austria). The electrolyte solution was $1 \mathrm{mM} \mathrm{KCl}$ and the channel height was adjusted to $100 \pm 5 \mathrm{~mm}$ before measurement. The $\mathrm{pH}$ of the solution was adjusted from 2.7 to 10.1 by an automatic titrator with a test interval of 0.3. Water contact angle was quantified using a drop shape analyzer (JC2000D4A, Zhongchen, Shanghai, China). $5 \mu \mathrm{L}$ of ultrapure water was dropped on the membrane surface using a $50 \mu \mathrm{L}$ glass syringe. After the ultrapure water droplets were dropped on the surface of the membrane for five seconds, the contact angle image between the surface and the water droplets was measured by a light microscope. For each condition, measurements were performed in triplicate using separate pieces of membrane.

\section{Results and Discussion}

\subsection{Filtration Performance of Pristine and Aged Membranes}

Pure water permeability reflects the intrinsic resistance of membrane to water flow, and it has been widely used as an indicator for the assessment of membrane aging [6,11,12]. In this study, pure water permeability was determined by filtering ultrapure water under a TMP of $60 \mathrm{kPa}$, and permeability of pristine and aged membranes were denoted as $L_{p 0}$ and $L_{p}$, respectively. Permeability of aged membranes normalized to that of pristine membrane $\left(\mathrm{L}_{\mathrm{p}} / \mathrm{L}_{\mathrm{p} 0}\right)$ are shown in Figure 1. It can be seen that $\mathrm{H}_{2} \mathrm{O}_{2}$ aging at both $\mathrm{pH} 9$ and 11 resulted in insignificant increase of membrane permeability (i.e., less than $10 \%$ ). However, permeability of membranes aged by $\mathrm{NaClO}$ at $\mathrm{pH} 9$ and 11 were increased to 5.75 and 3.84 times of that of the pristine membrane, respectively. Although the extent of increase varied depending on exposure dose and aging conditions, permeability increase of PES membrane due to $\mathrm{NaClO}$ aging has been reported in many studies [13,16,17,32-34], and it was commonly attributed to the increase of pore size and porosity [11]. The similar permeability of pristine, control, and $\mathrm{H}_{2} \mathrm{O}_{2}$-aged membranes suggested that pore structure of the PES membrane was not altered obviously by alkaline or $\mathrm{H}_{2} \mathrm{O}_{2}$ under the aging conditions in this work.

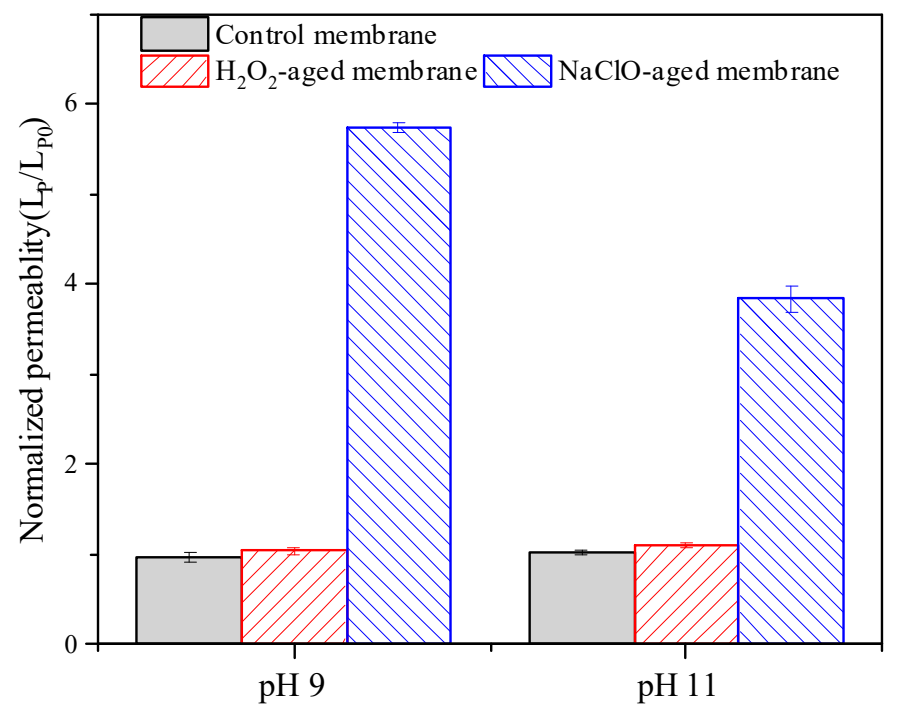

Figure 1. Effects of hydrogen peroxide $\left(\mathrm{H}_{2} \mathrm{O}_{2}\right)$ and sodium hypochlorite $(\mathrm{NaClO})$ aging on normalized permeability of polyethersulfone (PES) membrane. Control membrane indicates membrane samples aged in $\mathrm{NaOH}$ solution with $\mathrm{pH} 9$ or $11, \mathrm{c}\left(\mathrm{H}_{2} \mathrm{O}_{2}\right)=\mathrm{c}(\mathrm{NaClO})=5000 \mathrm{mg} / \mathrm{L}, \mathrm{t}=100 \mathrm{~h}$, and error bars indicate standard deviation of triplicate samples.

Fouling propensity and retention ability towards organic macromolecules are key performance factors of UF membrane. In this work, HA was used as a model organic foulant to evaluate the retention ability and fouling behavior of pristine and aged PES membranes because it was ubiquitous in natural water and has been identified as a major foulant. 
UMFI of pristine and aged membranes for HA filtration are presented in Figure 2. UMFI is a parameter for quantitative description of membrane fouling, and a higher value of UMFI means more serious fouling [31]. Compared with control membrane, UMFI was increased by $33.7 \%$ due to $\mathrm{H}_{2} \mathrm{O}_{2}$ aging at $\mathrm{pH} 9$, while the change of UMFI due to $\mathrm{H}_{2} \mathrm{O}_{2}$ aging at $\mathrm{pH} 11$ was less than $10 \%$. As for $\mathrm{NaClO}$ aging, UMFI was increased by $55.7 \%$ and $109.1 \%$ at $\mathrm{pH} 9$ and 11 , respectively. It can be seen that $\mathrm{H}_{2} \mathrm{O}_{2}$ aging resulted in much less increase of fouling propensity compared with $\mathrm{NaClO}$ aging.

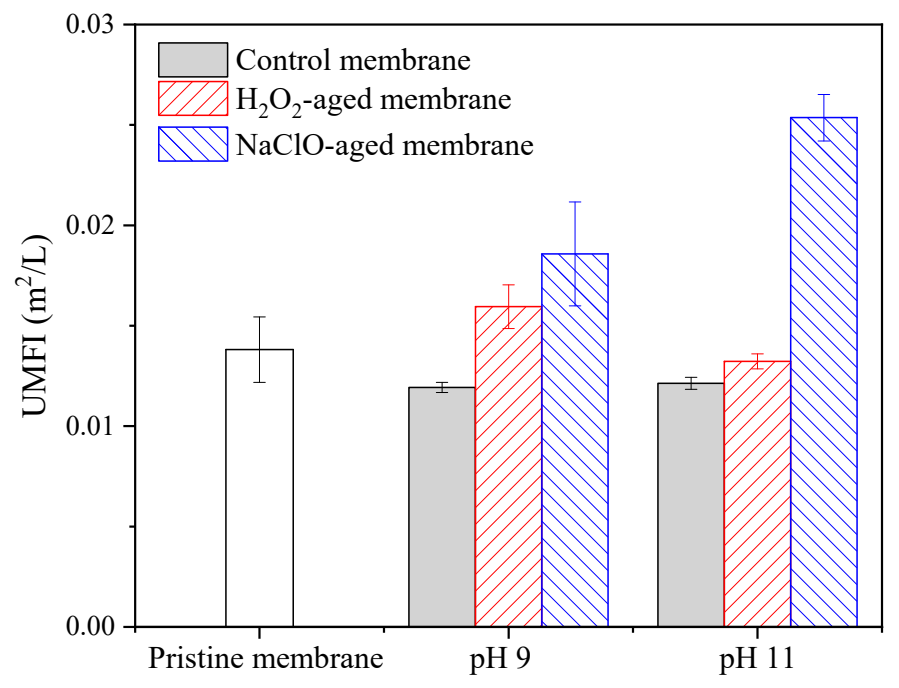

Figure 2. Effects of $\mathrm{H}_{2} \mathrm{O}_{2}$ and $\mathrm{NaClO}$ aging on fouling behavior of PES membrane during filtration of humic acid (HA) solution. Control membrane indicates membrane samples aged in $\mathrm{NaOH}$ solution with $\mathrm{pH} 9$ or $11, \mathrm{c}\left(\mathrm{H}_{2} \mathrm{O}_{2}\right)=\mathrm{c}(\mathrm{NaClO})=5000 \mathrm{mg} / \mathrm{L}, \mathrm{t}=100 \mathrm{~h}$, and error bars indicate standard deviation of triplicate samples.

Figure 3 shows HA retention rates of pristine and aged membranes. HA retention rate of pristine membrane was $59.2 \%$, and almost no change in HA retention ability was observed for control membranes. For membranes aged by $\mathrm{H}_{2} \mathrm{O}_{2}$ at $\mathrm{pH} 9$ and 11, the retention rates slightly decreased to $55.5 \%$ and $58.9 \%$, respectively. In contrast, the retention rates of membranes aged by $\mathrm{NaClO}$ at $\mathrm{pH} 9$ and 11 were significantly decreased to $19.9 \%$ and $37.2 \%$, respectively.

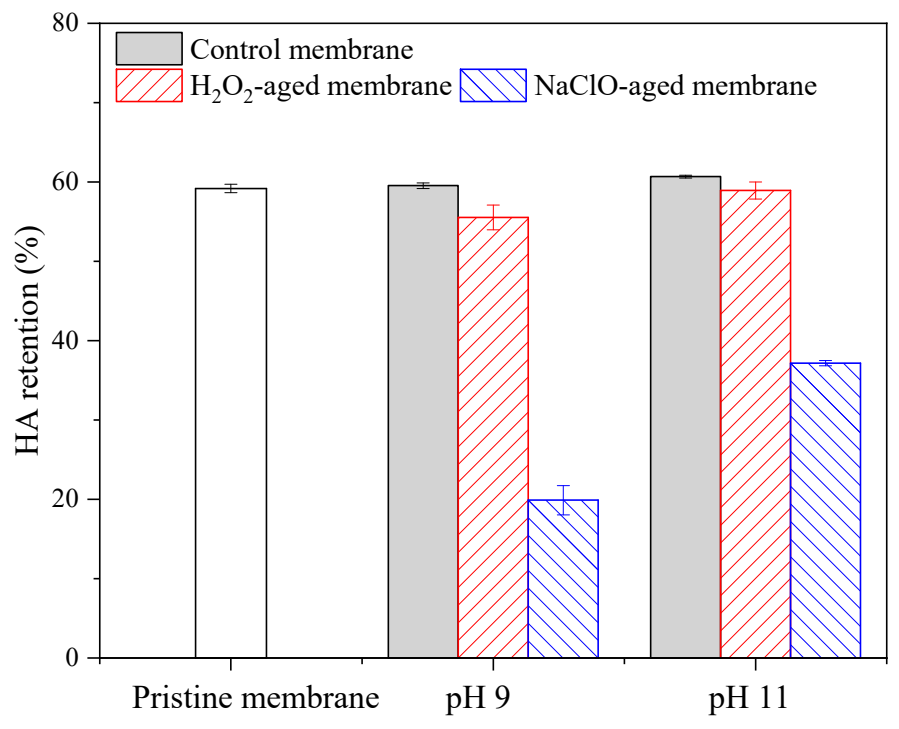

Figure 3. Effects of $\mathrm{H}_{2} \mathrm{O}_{2}$ and $\mathrm{NaClO}$ aging on $\mathrm{HA}$ retention rate of PES membrane. Control membrane indicates membrane samples aged in $\mathrm{NaOH}$ solution with $\mathrm{pH} 9$ or $11, \mathrm{c}\left(\mathrm{H}_{2} \mathrm{O}_{2}\right)=\mathrm{c}(\mathrm{NaClO})=5000 \mathrm{mg} / \mathrm{L}$, $\mathrm{t}=100 \mathrm{~h}$, and error bars indicate standard deviation of triplicate samples. 
Combining Figures 1-3, it can be concluded that degradation of the PES membrane due to NaClO exposure was much more serious than that by $\mathrm{H}_{2} \mathrm{O}_{2}$ exposure under the aging conditions in this work. Considering the comparable efficiency of $\mathrm{H}_{2} \mathrm{O}_{2}$ cleaning with $\mathrm{NaClO}$ cleaning [18], $\mathrm{H}_{2} \mathrm{O}_{2}$ is a better oxidative cleaning agent than $\mathrm{NaClO}$ because of the minimization of membrane degradation.

To elucidate the different influences of $\mathrm{H}_{2} \mathrm{O}_{2}$ and $\mathrm{NaClO}$ aging on membrane performance, properties of pristine and aged membranes were investigated at both a molecular scale (i.e., functional groups and elements composition) and a microscopic scale (i.e., surface morphology, hydrophilicity, and surface charge).

\subsection{Chemical Composition of Pristine and Aged Membranes}

The ATR-FTIR spectra of pristine and aged membranes are shown in Figure 4, and the relative absorbance strength at 1772, 1700, 1668, and $1032 \mathrm{~cm}^{-1}$ are listed in Table S2 in the Supplementary Information. For pristine membrane, apart from several characteristic peaks of PES (i.e., 1580, 1486, $1320,1292,1241,1150,1105 \mathrm{~cm}^{-1}$ ) exhibiting high absorption intensity, an obvious band at $1668 \mathrm{~cm}^{-1}$ was observed. The band at $1668 \mathrm{~cm}^{-1}$ represents the stretching vibration of the amide unit in PVP, and its intensity has been extensively used as an indicator of the content of PVP [16,34-37]. Similar to previous studies, $\mathrm{NaClO}$ aging caused decrease of intensity of the peak at $1668 \mathrm{~cm}^{-1}$ due to PVP oxidation /dislodgement, and new peaks at 1700 and $1772 \mathrm{~cm}^{-1}$ representing oxidation products of PVP were observed. Meanwhile, a new peak appeared at $1032 \mathrm{~cm}^{-1}$ due to $\mathrm{NaClO}$ aging. Although there is some controversy concerning the assignment of this peak, it can be ascribed to the formation of sulfonic acid group due to PES chain scission based on the variation of membrane surface charge, which will be discussed in Section 3.3. Compared with $\mathrm{NaClO}$ aging at $\mathrm{pH} 11, \mathrm{NaClO}$ aging at $\mathrm{pH} 9$ resulted in more dramatic changes in peak intensities at 1772,1700,1668, and $1032 \mathrm{~cm}^{-1}$, suggesting a much higher extent of PVP degradation and PES chain scission at $\mathrm{pH} 9$ than that at $\mathrm{pH}$ 11. $\mathrm{pH}$-dependent of PES/PVP degradation by $\mathrm{NaClO}$ has been reported in several studies, and it was usually attributed to the formation of hydroxyl radical in $\mathrm{NaClO}$ solution due to the coexistence of $\mathrm{ClO}^{-}$and $\mathrm{HClO}$ under neutral to weak alkaline conditions $[14,38,39]$. In contrast, neither decrease of the peak intensity at $1668 \mathrm{~cm}^{-1}$ nor appearance of new peaks at 1772, 1700, and $1032 \mathrm{~cm}^{-1}$ was observed for control and $\mathrm{H}_{2} \mathrm{O}_{2}$-aged membranes, indicating that PVP oxidation/dislodgement and PES chain scission was insignificant under the aging conditions here.

XPS analysis was conducted to further characterize membrane surface chemical composition of pristine and aged membranes, and atomic percentages of carbon, nitrogen, oxygen, sulfur, and chloride are listed in Table 1 . The presence of $4.14 \%$ of nitrogen atom further proved the PES membrane used in this study was blended with PVP because there is no nitrogen in pure PES. For membranes aged by $\mathrm{NaClO}$ at $\mathrm{pH} 9$ and 11 , the atomic percentage of nitrogen decreased to $2.40 \%$ and $2.59 \%$, respectively, which was qualitatively consistent with the decrease of peak intensity at $1668 \mathrm{~cm}^{-1}$ and demonstrated the dislodgement of PVP. Meanwhile, the incorporation of chloride was observed for $\mathrm{NaClO}$ aging, and the atomic percentage of chloride for membrane aged at $\mathrm{pH} 9$ was almost twice of that at 11 . Chloride was introduced onto the surface of $\mathrm{NaClO}$-aged membranes in the form of a phenyl chloride group along with the formation of sulfonic acid group during PES chain scission $[13,14,40]$. The higher percentage of chloride for the membrane aged by $\mathrm{NaClO}$ at $\mathrm{pH} 9$ indicated more serious PES chain scission by $\mathrm{NaClO}$ aging at $\mathrm{pH} 9$. With respect to $\mathrm{H}_{2} \mathrm{O}_{2}$ aging, although FTIR spectra indicated no peak intensity decrease of the PVP characteristic band (i.e., $1668 \mathrm{~cm}^{-1}$ ), the percentage of nitrogen decreased to $3.27 \%$ and $3.80 \%$ for $\mathrm{pH} 9$ and 11 , respectively. The seemingly contradictory results of ATR-FTIR and XPS analysis can be explained by the different analysis depth of the two techniques, with XPS providing chemical binding information for the top several nanometers of the surface while ATR-FTIR penetrating to a great depth of several micrometers [17,33]. Overall, combining the results of ATR-FTIR and XPS analysis, $\mathrm{NaClO}$ aging led to both chain scissions of PES and oxidation/dislodgement of PVP, whereas $\mathrm{H}_{2} \mathrm{O}_{2}$ aging only resulted in partial dislodgement of PVP from a region of very small thickness (Figure $\mathrm{S} 1$ in the Supplementary Information). 

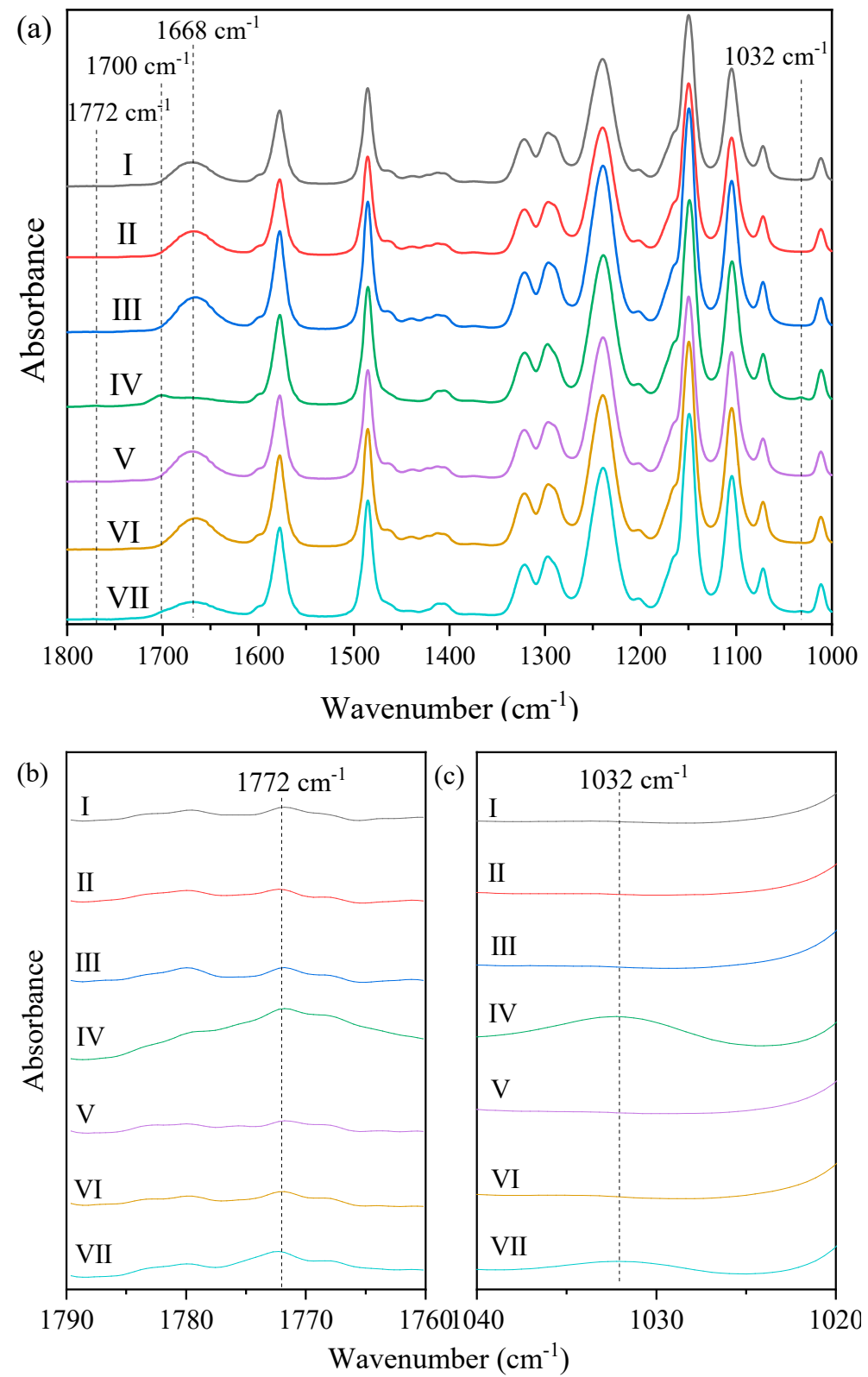

Figure 4. ATR-FTIR spectra of pristine and aged PES membrane: (a) 1800-1000 $\mathrm{cm}^{-1}$, (b) partial enlarged view of $1790-1760 \mathrm{~cm}^{-1}$, and (c) partial enlarged view of $1040-1020 \mathrm{~cm}^{-1}$. (I) pristine; (II) control (pH 9); (III) $\mathrm{H}_{2} \mathrm{O}_{2}$-aged ( $\mathrm{pH}$ 9); (IV) NaClO-aged (pH 9); (V) control (pH 11); (VI) $\mathrm{H}_{2} \mathrm{O}_{2}$-aged ( $\mathrm{pH} 11)$; and (VII) NaClO-aged ( $\mathrm{pH} 11)$. Control membrane indicates membrane samples aged in $\mathrm{NaOH}$ solution with $\mathrm{pH} 9$ or $11, \mathrm{c}\left(\mathrm{H}_{2} \mathrm{O}_{2}\right)=\mathrm{c}(\mathrm{NaClO})=5000 \mathrm{mg} / \mathrm{L}, \mathrm{t}=100 \mathrm{~h}$.

Table 1. Atomic percentage of elements (at \%) of pristine and aged PES membranes. Control membrane indicates membrane samples aged in $\mathrm{NaOH}$ solution with $\mathrm{pH} 9$ or $11, \mathrm{c}\left(\mathrm{H}_{2} \mathrm{O}_{2}\right)=\mathrm{c}(\mathrm{NaClO})=5000 \mathrm{mg} / \mathrm{L}$, $\mathrm{t}=100 \mathrm{~h}$.

\begin{tabular}{cccccccc}
\hline \multirow{2}{*}{ Element. } & \multirow{2}{*}{ Pristine } & \multicolumn{3}{c}{$\mathbf{p H} \mathbf{9}$} & \multicolumn{3}{c}{$\mathbf{p H} \mathbf{~ 1 1}$} \\
\cline { 3 - 7 } & & Control & $\mathbf{H}_{\mathbf{2}} \mathbf{O}_{\mathbf{2}}$-Aged & $\mathbf{N a C l O - A g e d}$ & Control & $\mathbf{H}_{\mathbf{2}} \mathbf{O}_{\mathbf{2}}$-Aged & NaClO-Aged \\
\hline $\mathrm{C}$ & 73.72 & 74.47 & 73.66 & 71.15 & 74.57 & 74.51 & 72.49 \\
$\mathrm{~N}$ & 4.14 & 4.57 & 3.27 & 2.40 & 4.30 & 3.80 & 2.59 \\
$\mathrm{O}$ & 17.65 & 16.65 & 17.71 & 18.88 & 16.35 & 16.65 & 18.51 \\
$\mathrm{~S}$ & 4.50 & 4.31 & 5.35 & 6.26 & 4.79 & 5.03 & 5.72 \\
$\mathrm{Cl}$ & - & - & - & 1.30 & - & - & 0.69 \\
\hline
\end{tabular}




\subsection{Morphology and Surface Properties of Pristine and Aged Membranes}

SEM images of pristine and aged PES membranes are shown in Figure 5. It can be seen that membrane surface morphology and pore structure was almost unchanged by alkaline and $\mathrm{H}_{2} \mathrm{O}_{2}$ aging in this study. The partial dislodgement of PVP from membrane surface revealed by XPS analysis did not resulted in visible change in membrane pore structure. This could explain why $\mathrm{H}_{2} \mathrm{O}_{2}$ aging did not result in obvious change in membrane permeability and retention ability. In contrast, $\mathrm{NaClO}$ aging led to significant increase of membrane pore size, especially at $\mathrm{pH} 9$ (Figure $5 \mathrm{~d}$ ), which can be attributed to the substantial PES chain scission and PVP degradation [16], and can explain the remarkable increase in membrane permeability and decrease in HA retention rate.

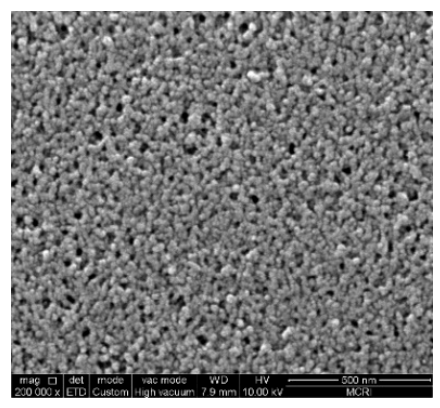

(a)

$\mathrm{pH} 9$

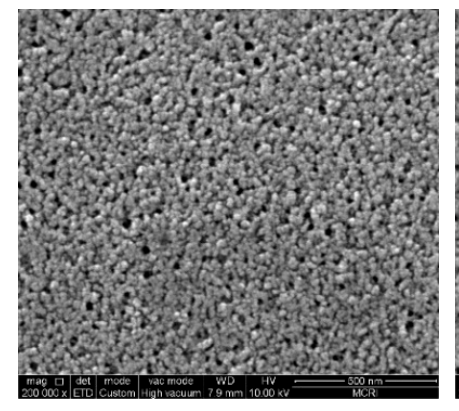

(b)

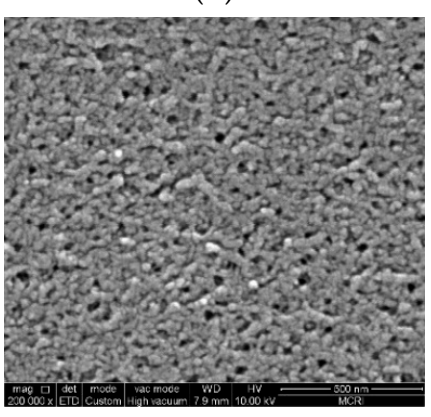

(e)

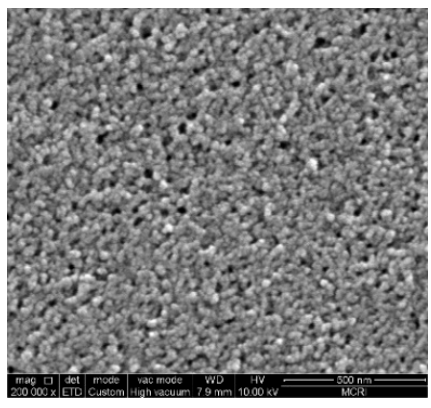

(c)

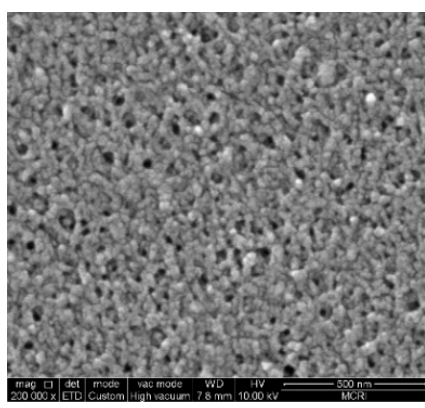

(f)

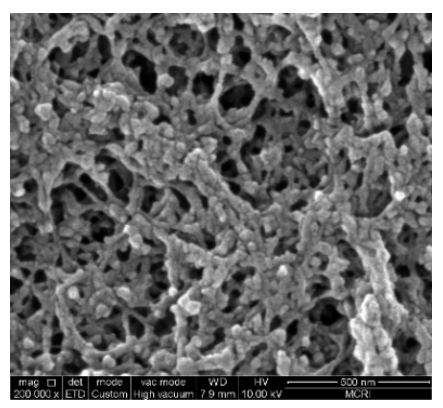

(d)

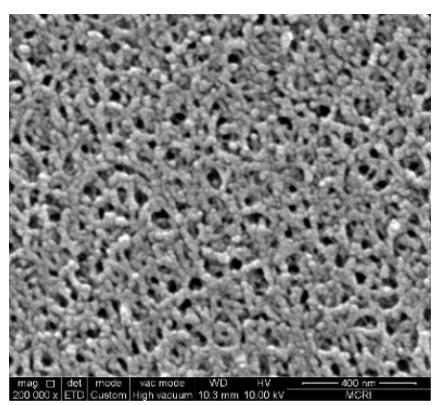

$(\mathrm{g})$

Figure 5. SEM images of pristine and aged PES membrane at the magnification of 200 000: (a) pristine; (b) control (pH 9); (c) $\mathrm{H}_{2} \mathrm{O}_{2}$-aged ( $\mathrm{pH}$ 9); (d) NaClO-aged (pH 9); (e) control (pH 11); (f) $\mathrm{H}_{2} \mathrm{O}_{2}$-aged ( $\mathrm{pH} 11)$; and (g) NaClO-aged ( $\mathrm{pH}$ 11). Control membrane indicates membrane samples aged in $\mathrm{NaOH}$ solution with $\mathrm{pH} 9$ or $11, \mathrm{c}\left(\mathrm{H}_{2} \mathrm{O}_{2}\right)=\mathrm{c}(\mathrm{NaClO})=5000 \mathrm{mg} / \mathrm{L}, \mathrm{t}=100 \mathrm{~h}$.

Figure 6 shows the variation of zeta potentials of pristine and aged membranes in the $\mathrm{pH}$ range from of 2.7-10.1. The pristine membrane exhibited an isoelectric point (IEP) of about 2.7, and the negative charge increased with solution $\mathrm{pH}$, indicating the presence of weak acid groups such as carboxylic acid groups $[14,40]$. The zeta potentials of control and $\mathrm{H}_{2} \mathrm{O}_{2}$-aged membranes were similar with that of pristine membrane, suggesting that alkaline and $\mathrm{H}_{2} \mathrm{O}_{2}$ aging did not alter ionizable 
functional groups on membrane surface, which was consistent with the result of ATR-FTIR. However, the IEP of membranes aged by $\mathrm{NaClO}$ disappeared and negative charge at solution $\mathrm{pH}$ around 3 increased substantially, indicating the formation of strong acid functional groups. Therefore, the peak formed at $1032 \mathrm{~cm}^{-1}$ in ATR-FTIR analysis (Figure 4c) was assigned to sulfonic acid group [14,40]. At solution $\mathrm{pH}$ around 3, the negative charge of the membrane aged by $\mathrm{NaClO}$ at $\mathrm{pH} 9$ was higher than that aged by $\mathrm{NaClO}$ at $\mathrm{pH} 11$, which was consistent with the more serious PES chain scission demonstrated by ATR-FTIR and XPS analysis. Moreover, compared with membrane aged by $\mathrm{NaClO}$ at $\mathrm{pH} 9$, the membrane aged by $\mathrm{NaClO}$ at $\mathrm{pH} 11$ exhibited steeper increase of negative charge with the increase of solution $\mathrm{pH}$. The difference suggested that more carboxylic acid groups generated by PVP oxidation present on membrane surface, which could be ascribed to less dislodgement of oxidation products at $\mathrm{pH} 11$.

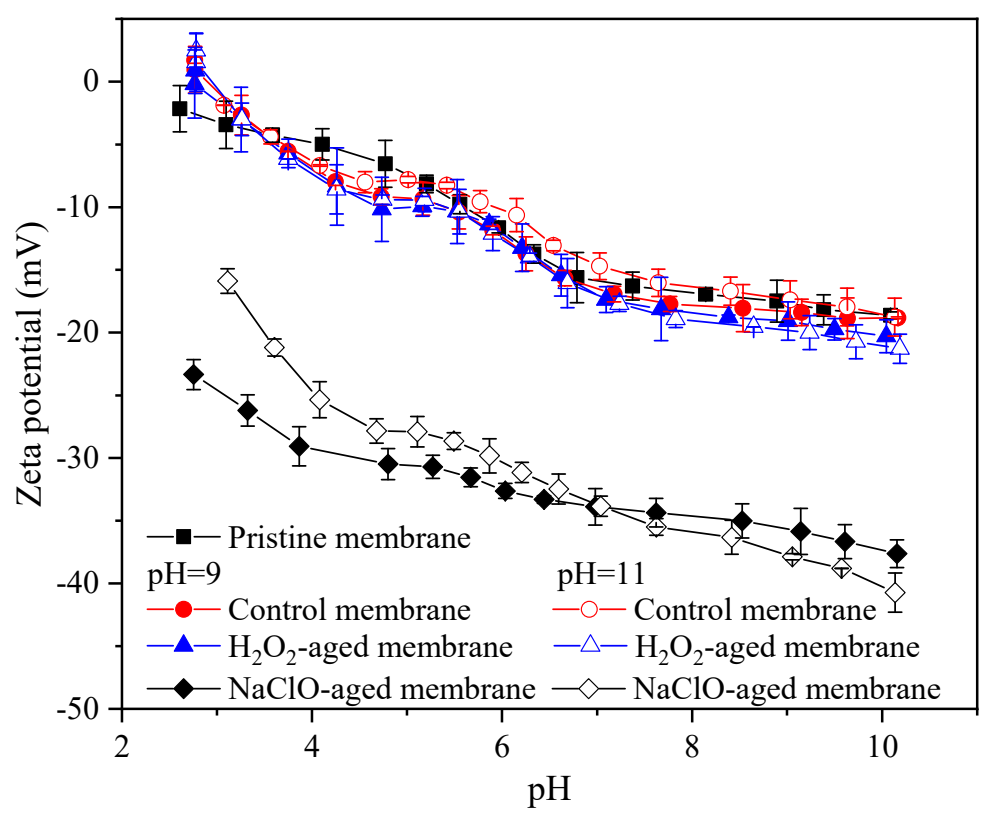

Figure 6. Effects of $\mathrm{H}_{2} \mathrm{O}_{2}$ and $\mathrm{NaClO}$ aging on $\mathrm{pH}$ dependence of the zeta potential of PES membrane. Control membrane indicates membrane samples aged in $\mathrm{NaOH}$ solution with $\mathrm{pH} 9$ or $11, \mathrm{c}\left(\mathrm{H}_{2} \mathrm{O}_{2}\right)=$ $\mathrm{c}(\mathrm{NaClO})=5000 \mathrm{mg} / \mathrm{L}, \mathrm{t}=100 \mathrm{~h}$, and error bars indicate standard deviation of triplicate samples.

The water contact angles of pristine and aged membranes are shown in Figure 7. Water contact angle of pristine membrane was $44.7^{\circ}$, which was lower than pure PES material probably due to blending with PVP [33]. $\mathrm{H}_{2} \mathrm{O}_{2}$ aging resulted in some increase of water contact angle, which might be ascribed to the dislodgement of some PVP from membrane surface as revealed by XPS analysis (Table 1). The increase of water contact angle can explain the slight increase of fouling propensity of $\mathrm{H}_{2} \mathrm{O}_{2}$-aged membrane (Figure 2). However, $\mathrm{NaClO}$ aging at $\mathrm{pH} 9$ and 11 decreased the water contact angle to $36.9^{\circ}$ and $41.2^{\circ}$, respectively. Although dislodgement of hydrophilic additive (i.e., PVP) generally leads to decrease of hydrophilicity and increase of water contact angle, the decrease of water contact angle due to $\mathrm{NaClO}$ aging has been reported in several previous studies and was attributed to the increase of membrane pore size and capillary effect $[7,36]$. In fact, the variation of water contact angle was decided by several factors, including loss of hydrophilic additive, increase of pore size, and increase of negative charge due to PES and PVP degradation. The decrease of water contact angle here did not lead to the alleviation of hydrophobic interactions. Moreover, increase of membrane pore size might also result in the change of fouling type and increase of fouling propensity [41]. Therefore, although $\mathrm{NaClO}$ aging caused a decrease of water contact angle and increase of surface negative charge, fouling propensity of membrane aged by $\mathrm{NaClO}$ was increased. 


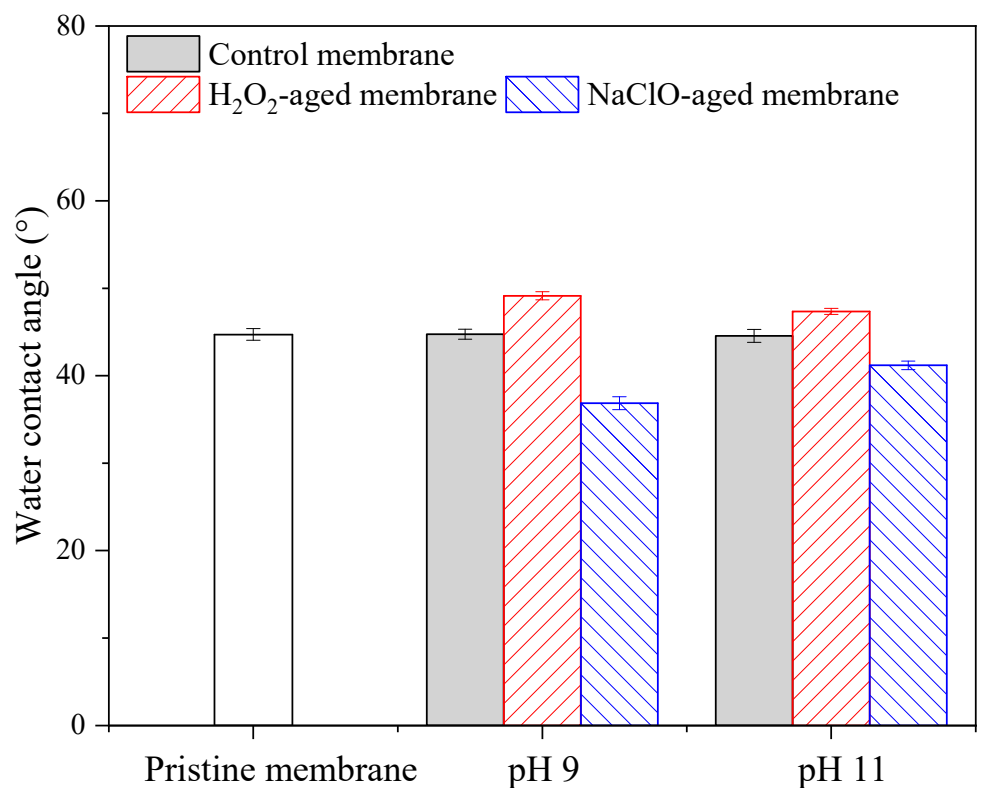

Figure 7. Effects of $\mathrm{H}_{2} \mathrm{O}_{2}$ and $\mathrm{NaClO}$ aging on pure water contact angle of PES membrane. Control membrane indicates membrane samples aged in $\mathrm{NaOH}$ solution with $\mathrm{pH} 9$ or $11, \mathrm{c}\left(\mathrm{H}_{2} \mathrm{O}_{2}\right)=\mathrm{c}(\mathrm{NaClO})$ $=5000 \mathrm{mg} / \mathrm{L}, \mathrm{t}=100 \mathrm{~h}$, and error bars indicate standard deviation of triplicate samples.

\section{Conclusions}

In this study, effects of $\mathrm{H}_{2} \mathrm{O}_{2}$ and $\mathrm{NaClO}$ exposure under alkaline condition ( $\mathrm{pH} 9$ and 11) on filtration performance and physicochemical properties of PES membrane were comprehensively investigated. $\mathrm{H}_{2} \mathrm{O}_{2}$ aging did not result in obvious change in membrane permeability and retention ability, whereas $\mathrm{NaClO}$ aging led to remarkable increase of permeability and substantial decrease of retention ability. Meanwhile, $\mathrm{H}_{2} \mathrm{O}_{2}$ aging slightly increased fouling propensity during HA filtration, while $\mathrm{NaClO}$ aging resulted in more serious fouling. ATR-FTIR and XPS analysis suggested that $\mathrm{H}_{2} \mathrm{O}_{2}$ aging resulted in partial dislodgement of PVP from membrane surface, but the main polymer was not degraded. Therefore, membrane hydrophilicity was slightly decreased, while membrane morphology and surface charge remained unchanged. In contrast, $\mathrm{NaClO}$ aging not only resulted in substantial oxidation and dislodgement of PVP, but also caused chain scission of PES, leading to significant increase in membrane pore size and surface charge. Overall, the degree of membrane degradation caused by $\mathrm{H}_{2} \mathrm{O}_{2}$ exposure was much lower than that by $\mathrm{NaClO}$ exposure, and aging of PES membrane due to chemical cleaning can be minimized by using $\mathrm{H}_{2} \mathrm{O}_{2}$ as cleaning agent.

Supplementary Materials: The following are available online at http://www.mdpi.com/1660-4601/16/20/3972/s1, Figure S1. Schematic diagram of PES and PVP degradation by $\mathrm{H}_{2} \mathrm{O}_{2}$ and $\mathrm{NaClO}$. For $\mathrm{H}_{2} \mathrm{O}_{2}$ aging, no PES degradation was detected by FTIR, XPS or zeta potential measurement, while XPS indicated partial loss of PVP from membrane surface with a very small thickness (several $\mathrm{nm}$ ). For $\mathrm{NaClO}$ aging, the formation of sulfonic acid group revealed by FTIR $\left(1032 \mathrm{~cm}^{-1}\right)$, the incorporation of chloride revealed by XPS, and the increase of membrane surface negative charge suggested chain scission of part PES, while two degradation products of PVP, i.e., succinimide and carboxyl group due to opening of the pyrrolidone ring, was proved by FTIR $\left(1700 / 1772 \mathrm{~cm}^{-1}\right)$ and zeta potential measurement, respectively. Phenyl chloride and carboxyl group were not detected by FTIR probably due to their relatively low abundance. Table S1: Characteristics of PES membrane (UP150 P) provided by the manufacturer. Table S2: The relative absorbance strength of pristine and aged PES membranes at 1772, 1700,1668 and $1032 \mathrm{~cm}^{-1}$ by normalizing to the absorbance at $1240 \mathrm{~cm}^{-1}$. Control membrane indicates membrane samples aged in $\mathrm{NaOH}$ solution with $\mathrm{pH} 9$ or $11, \mathrm{c}\left(\mathrm{H}_{2} \mathrm{O}_{2}\right)=\mathrm{c}(\mathrm{NaClO})=5000 \mathrm{mg} / \mathrm{L}, \mathrm{t}=100 \mathrm{~h}$.

Author Contributions: Conceptualization, K.L.; Data curation, S.L. and Q.S.; Funding acquisition, K.L.; Investigation, K.L., G.W. and T.H.; Methodology, Q.S.; Writing—original draft, S.L.; Writing—review \& editing, K.L., G.W. and T.H.

Funding: This research was jointly supported by National Natural Science Foundation of China (51608427), Key Research and Development Program of Shaanxi province (2019ZDLSF06-01), and The Youth Innovation Team of Shaanxi Universities Funded by Education Department of Shaanxi Province. 
Conflicts of Interest: The authors declare no conflict of interest.

\section{References}

1. Cheng, X.; Zhou, W.; Li, P.; Ren, Z.; Wu, D.; Luo, C.; Tang, X.; Wang, J.; Liang, H. Improving ultrafiltration membrane performance with pre-deposited carbon nanotubes/nanofibers layers for drinking water treatment. Chemosphere 2019, 234, 545-557. [CrossRef] [PubMed]

2. Walker, S.; Narbaitz, R.M. Hollow fiber ultrafiltration of Ottawa River water: Floatation versus sedimentation pre-treatment. Chem. Eng. J. 2016, 288, 228-237. [CrossRef]

3. Shao, S.; Fu, W.; Li, X.; Shi, D.; Jiang, Y.; Li, J.; Gong, T.; Li, X. Membrane fouling by the aggregations formed from oppositely charged organic foulants. Water Res. 2019, 159, 95-101. [CrossRef] [PubMed]

4. Li, K.; Wen, G.; Li, S.; Chang, H.; Shao, S.; Huang, T.; Li, G.; Liang, H. Effect of pre-oxidation on low pressure membrane (LPM) for water and wastewater treatment: A review. Chemosphere 2019, 231, 287-300. [CrossRef] [PubMed]

5. Wang, Z.; Ma, J.; Tang, C.Y.; Kimura, K.; Wang, Q.; Han, X. Membrane cleaning in membrane bioreactors: A review. J. Membr. Sci. 2014, 468, 276-307. [CrossRef]

6. Regula, C.; Carretier, E.; Wyart, Y.; Gesan-Guiziou, G.; Vincent, A.; Boudot, D.; Moulin, P. Chemical cleaning/disinfection and ageing of organic UF membranes: A review. Water Res. 2014, 56, 325-365. [CrossRef]

7. Rabuni, M.F.; Nik Sulaiman, N.M.; Aroua, M.K.; Hashim, N.A. Effects of Alkaline Environments at Mild Conditions on the Stability of PVDF Membrane: An Experimental Study. Ind. Eng. Chem. Res. 2013, 52, 15874-15882. [CrossRef]

8. Alresheedi, M.T.; Basu, O.D.; Barbeau, B. Chemical cleaning of ceramic ultrafiltration membranes - Ozone versus conventional cleaning chemicals. Chemosphere 2019, 226, 668-677. [CrossRef]

9. Shao, S.; Wang, Y.; Shi, D.; Zhang, X.; Tang, C.Y.; Liu, Z.; Li, J. Biofouling in ultrafiltration process for drinking water treatment and its control by chlorinated-water and pure water backwashing. Sci Total Environ 2018, 644, 306-314. [CrossRef]

10. Zhang, X.; Liu, Y. Halogenated organics generated during online chemical cleaning of MBR: An emerging threat to water supply and public health. Sci. Total Environ. 2019, 656, 547-549. [CrossRef]

11. Robinson, S.; Abdullah, S.Z.; Bérubé, P.; Le-Clech, P. Ageing of membranes for water treatment: Linking changes to performance. J. Membr. Sci. 2016, 503, 177-187. [CrossRef]

12. Tsehaye, M.T.; Velizarov, S.; Van der Bruggen, B. Stability of polyethersulfone membranes to oxidative agents: A review. Polym. Degrad. Stabil. 2018, 157, 15-33. [CrossRef]

13. Kourde-Hanafi, Y.; Loulergue, P.; Szymczyk, A.; Van der Bruggen, B.; Nachtnebel, M.; Rabiller-Baudry, M.; Audic, J.-L.; Pölt, P.; Baddari, K. Influence of PVP content on degradation of PES/PVP membranes: Insights from characterization of membranes with controlled composition. J. Membr. Sci. 2017, 533, 261-269. [CrossRef]

14. Hanafi, Y.; Loulergue, P.; Ababou-Girard, S.; Meriadec, C.; Rabiller-Baudry, M.; Baddari, K.; Szymczyk, A. Electrokinetic analysis of PES/PVP membranes aged by sodium hypochlorite solutions at different $\mathrm{pH}$. J. Membr. Sci. 2016, 501, 24-32. [CrossRef]

15. Prulho, R.; Therias, S.; Rivaton, A.; Gardette, J.-L. Ageing of polyethersulfone/polyvinylpyrrolidone blends in contact with bleach water. Polym. Degrad. Stabil. 2013, 98, 1164-1172. [CrossRef]

16. Zhou, Z.; Huang, G.; Xiong, Y.; Zhou, M.; Zhang, S.; Tang, C.Y.; Meng, F. Unveiling the Susceptibility of Functional Groups of Poly(ether sulfone)/Polyvinylpyrrolidone Membranes to NaOCl: A Two-Dimensional Correlation Spectroscopic Study. Environ. Sci. Technol. 2017, 51, 14342-14351. [CrossRef] [PubMed]

17. Pellegrin, B.; Prulho, R.; Rivaton, A.; Thérias, S.; Gardette, J.-L.; Gaudichet-Maurin, E.; Causserand, C. Multi-scale analysis of hypochlorite induced PES/PVP ultrafiltration membranes degradation. J. Membr. Sci. 2013, 447, 287-296. [CrossRef]

18. Li, K.; Li, S.; Huang, T.; Dong, C.; Li, J.; Zhao, B.; Zhang, S. Chemical Cleaning of Ultrafiltration Membrane Fouled by Humic Substances: Comparison between Hydrogen Peroxide and Sodium Hypochlorite. Int. J. Environ. Res. Public Health 2019, 16, 2568. [CrossRef] 
19. Zou, J.; Cai, H.; Wang, D.; Xiao, J.; Zhou, Z.; Yuan, B. Spectrophotometric determination of trace hydrogen peroxide via the oxidative coloration of DPD using a Fenton system. Chemosphere 2019, 224, 646-652. [CrossRef]

20. Wang, X.; Hu, T.; Wang, Z.; Li, X.; Ren, Y. Permeability recovery of fouled forward osmosis membranes by chemical cleaning during a long-term operation of anaerobic osmotic membrane bioreactors treating low-strength wastewater. Water Res. 2017, 123, 505-512. [CrossRef]

21. Strugholtz, S.; Sundaramoorthy, K.; Panglisch, S.; Lerch, A.; Brügger, A.; Gimbel, R. Evaluation of the performance of different chemicals for cleaning capillary membranes. Desalination 2005, 179, 191-202. [CrossRef]

22. Ling, R.; Yu, L.; Pham, T.P.T.; Shao, J.; Chen, J.P.; Reinhard, M. The tolerance of a thin-film composite polyamide reverse osmosis membrane to hydrogen peroxide exposure. J. Membr. Sci. 2017, 524, 529-536. [CrossRef]

23. Yu, L.; Ling, R.; Chen, J.P.; Reinhard, M. Quantitative assessment of the iron-catalyzed degradation of a polyamide nanofiltration membrane by hydrogen peroxide. J. Membr. Sci. 2019, 588. [CrossRef]

24. Yu, W.; Graham, N.; Liu, T. Prevention of UF membrane fouling in drinking water treatment by addition of $\mathrm{H}_{2} \mathrm{O}_{2}$ during membrane backwashing. Water Res. 2019, 149, 394-405. [CrossRef] [PubMed]

25. Wu, Q.; Zhang, X.; Cao, G. Impacts of sodium hydroxide and sodium hypochlorite aging on polyvinylidene fluoride membranes fabricated with different methods. J. Environ. Sci. 2018, 67, 294-308. [CrossRef]

26. Klassen, N.V.; Marchington, D.; McGowan, H.C.E. $\mathrm{H}_{2} \mathrm{O}_{2}$ determination by the $\mathrm{I}_{3}{ }^{-}$method and by $\mathrm{KMnO}_{4}$ titration. Anal. Chem. 1994, 66, 2921-2925. [CrossRef]

27. Yadav, K.; Morison, K.; Staiger, M.P. Effects of hypochlorite treatment on the surface morphology and mechanical properties of polyethersulfone ultrafiltration membranes. Polym. Degrad. Stabil. 2009, 94, 1955-1961. [CrossRef]

28. Porcelli, N.; Judd, S. Chemical cleaning of potable water membranes: A review. Sep. Purif. Technol. 2010, 71, 137-143. [CrossRef]

29. Wang, X.; Ma, J.; Wang, Z.; Chen, H.; Liu, M.; Wu, Z. Reinvestigation of membrane cleaning mechanisms using NaOCl: Role of reagent diffusion. J. Membr. Sci. 2018, 550, 278-285. [CrossRef]

30. Li, K.; Liang, H.; Qu, F.; Shao, S.; Yu, H.; Han, Z.-s.; Du, X.; Li, G. Control of natural organic matter fouling of ultrafiltration membrane by adsorption pretreatment: Comparison of mesoporous adsorbent resin and powdered activated carbon. J. Membr. Sci. 2014, 471, 94-102. [CrossRef]

31. Huang, H.; Young, T.A.; Jacangelo, J.G. Unified Membrane Fouling Index for Low Pressure Membrane Filtration of Natural Waters: Principles and Methodology. Environ. Sci. Technol. 2008, 42, 714-720. [CrossRef] [PubMed]

32. Malczewska, B.; Zak, A. Structural Changes and Operational Deterioration of the Uf Polyethersulfone (Pes) Membrane Due to Chemical Cleaning. Sci. Rep. 2019, 9, 422. [CrossRef] [PubMed]

33. Arkhangelsky, E.; Kuzmenko, D.; Gitis, V. Impact of chemical cleaning on properties and functioning of polyethersulfone membranes. J. Membr. Sci. 2007, 305, 176-184. [CrossRef]

34. Causserand, C.; Pellegrin, B.; Rouch, J.-C. Effects of sodium hypochlorite exposure mode on PES/PVP ultrafiltration membrane degradation. Water Res. 2015, 85, 316-326. [CrossRef] [PubMed]

35. Silva, M.F.; da Silva, C.A.; Fogo, F.C.; Pineda, E.A.G.; Hechenleitner, A.A.W. Thermal and FTIR study of polyvinylpyrrolidone/lignin blends. J. Therm. Anal. Calorim. 2005, 79, 367-370. [CrossRef]

36. Hajibabania, S.; Antony, A.; Leslie, G.; Le-Clech, P. Relative impact of fouling and cleaning on PVDF membrane hydraulic performances. Sep. Purif. Technol. 2012, 90, 204-212. [CrossRef]

37. Rabiller-Baudry, M.; Bouzin, A.; Hallery, C.; Girard, J.; Leperoux, C. Evidencing the chemical degradation of a hydrophilised PES ultrafiltration membrane despite protein fouling. Sep. Purif. Technol. 2015, 147, 62-81. [CrossRef]

38. Touffet, A.; Baron, J.; Welte, B.; Joyeux, M.; Teychene, B.; Gallard, H. Impact of pretreatment conditions and chemical ageing on ultrafiltration membrane performances. Diagnostic of a coagulation/adsorption/filtration process. J. Membr. Sci. 2015, 489, 284-291. [CrossRef]

39. Wienk, I.; Meuleman, E.; Borneman, Z.; Boomgaard, T.; Smolders, C. Chemical treatment of membranes of a polymer blend: Mechanism of the reaction of hypochlorite with poly (vinyl pyrrolidone). J. Polym. Sci. Pol. Chem. 1995, 33, 49-54. [CrossRef] 
40. Hanafi, Y.; Szymczyk, A.; Rabiller-Baudry, M.; Baddari, K. Degradation of Poly(Ether Sulfone)/Polyvinylpyrrolidone Membranes by Sodium Hypochlorite: Insight from Advanced Electrokinetic Characterizations. Environ. Sci. Technol. 2014, 48, 13419-13426. [CrossRef]

41. Zhang, Y.; Wang, J.; Gao, F.; Chen, Y.; Zhang, H. A comparison study: The different impacts of sodium hypochlorite on PVDF and PSF ultrafiltration (UF) membranes. Water Res. 2017, 109, 227-236. [CrossRef] [PubMed]

(C) 2019 by the authors. Licensee MDPI, Basel, Switzerland. This article is an open access article distributed under the terms and conditions of the Creative Commons Attribution (CC BY) license (http://creativecommons.org/licenses/by/4.0/). 